\title{
Bidirectional exchanges of benthic invertebrates in a large river-floodplain system (Paraná River, Argentina)
}

\author{
Leticia M. Mesa ${ }^{1 *}$, Mercedes R. Marchese ${ }^{1,2}$, Luciana Montalto ${ }^{1,2}$ and Florencia L. Zilli ${ }^{1}$ \\ ${ }^{1}$ Instituto Nacional de Limnología (CONICET-UNL), Ciudad Universitaria, C.P. 3000, Santa Fe, Argentina \\ ${ }^{2}$ Facultad de Humanidades y Ciencias, Universidad Nacional del Litoral, Ciudad Universitaria, C.P. 3000, Santa Fe, Argentina
}

Received 30 March 2012; Accepted 2 November 2012

\begin{abstract}
The flood pulse regime and the hydrological connectivity determine the lateral bidirectional exchanges of water, chemical compounds, and biota between the river and the floodplain habitats. The primary goal of the present research was to analyze the effect of water flow on macroinvertebrates in two water levels in a lateral connectivity gradient, from the main channel through a connection channel to a permanently connected lake. We tested the hypothesis that the water flow from the main channel to the floodplain habitats during high water level causes a decrease in beta diversity between the sites, increasing similarity in the system. To test this hypothesis, we sampled a river-floodplain-lake system of the Middle Paraná River during two water levels, and analyzed the spatial and temporal turnover of species between sites and habitats. Local physical characteristics, such as depth, benthic particulate organic matter, and grain size of bottom sediments influenced assemblage composition. Taxa richness, density, and Shannon diversity differed among habitats within the river-lake system, but did not show significant differences between water levels. Richness, density, and diversity were higher in the lake and the connection channel than in the Paraná River bank. Beta diversity was significantly higher during high water period. During low water period, benthic assemblage composition was homogenized, as reflected by the lower values of species turnover between the sites situated in the main channel-lake corridor during this phase. The lateral bidirectional exchanges among the habitats are essential for maintaining the specific invertebrate diversity of large river corridors.
\end{abstract}

Key words: Hydrological connectivity / species turnover / lateral corridor / floodplain lake

\section{Introduction}

Understanding spatiotemporal variation in biotic patterns and their relationships with the environment is a key challenge in riverine and floodplain ecology, including that of floodplain rivers (Poff, 1997; Ward et al., 1999; Ward and Tockner, 2001; Amoros and Bornette, 2002; Thorp et al., 2006). River-floodplain systems are shaped by the characteristic flood pulse regime (Junk et al., 1989; Junk, 1999; Tockner et al., 2000; Wantzen and Junk, 2000) and the extent of lateral hydrological connectivity (Amoros et al., 1987; Ward and Stanford, 1995; Amoros and Bornette, 2002). Hydrological connectivity establishes a bidirectional pathway for the exchange of biota and material among patches between the river and the floodplain habitats at various spatial and temporal scales (Tockner et al., 2000; Amoros and Bornette, 2002; Bunn and Arthington, 2002). Natural water level fluctuations

\footnotetext{
*Corresponding author: letimesa@hotmail.com
}

facilitate the exchange of water, sediments, nutrients, and biota through connections among landscape elements, and these transfers are considered to be essential for the functioning and integrity of these systems, generating and sustaining the habitat's heterogeneity (Neiff, 2001; Amoros and Bornette, 2002).

For neotropical rivers with active floodplains, our understanding of biodiversity patterns in the lateral dimension has originated from concepts developed specifically for, and from, these river types (e.g., Ezcurra de Drago et al., 2004). In these rivers, the increase of biodiversity from the main channel to the floodplain habitats has indeed been shown to occur (Ezcurra de Drago et al., 2004). Despite these insights, it is uncertain how the interaction between the water flow direction and the hydrological connectivity influences the turnover of macroinvertebrates in floodplain systems. The magnitude, pathway, and distance through which the floodwater transports the biota - particularly macroinvertebrates to newly inundated habitats in a lateral connectivity gradient are still unknown. Therefore, in order to help fill 
the gaps in this knowledge, the primary goal of the present research was to analyze the effect of water flow on macroinvertebrates in high and low water levels, in a lateral connectivity gradient, from the main channel through a connection channel to a permanently connected lake. We tested the hypothesis that water flow from the main channel to the floodplain habitats during high water level causes a decrease in beta diversity among the sites, increasing similarity in the system.

\section{Methods}

\section{Study area}

The main channel of the Middle Paraná reach exhibits a braided pattern with a fringing floodplain, showing a sequence of wide reaches with two or more anabranches, followed by short reaches with a single-thread channel. The channel sinuosity is 1.2 and the mean slope is $0.045 \mathrm{~m} . \mathrm{km}^{-1}$ (Drago, 1990). The Paraná River displays unimodal seasonal hydrographs influenced mainly by rainfall pattern, with a high level stage during the first 6 months of the year and maximum peaks in March-April. Low water levels occur in the second half of the year, with minimum flows in September-October (Marchese et al., 2002).

This study was conducted in the linked structural elements (habitats) of the floodplain-river landscape of the Middle Paraná River $\left(31^{\circ} 41^{\prime} \mathrm{S}, 60^{\circ} 43^{\prime} \mathrm{W}\right)$ near Santa Fe city (CE Argentina): (1) the right bank of the main channel, (2) in a floodplain lake (of $0.39 \mathrm{~km}^{2}$ area and a maximum depth of $4.6 \mathrm{~m}$ ) permanently connected to a secondary channel (Miní River) and to the main channel, and (3) their connection channel (0.74 km long) (Fig. 1). The studied floodplain habitats are located in an elevated zone of the alluvial valley (Fig. 1). During the rising and inundation phases, the flooding water first enters the floodplain through the floodplain channels by overbanking (Drago, 2007). In the study area, when the water level reaches $13.6 \mathrm{~m}$ a.s.l. during high water, the floodplain secondary channel (Miní River) connects the floodplain habitats with the main channel upstream (Ramonell et al., 2000). Then, during low water levels, the main flow direction is from the Paraná River through the connection channel to the lake. This condition determines that the flow direction is NE-SW during the high water phase and its inverse during the low water phase (Fig. 1).

\section{Sampling design}

Within each habitat, different sites were sampled. The sampling sites were situated near the bank of the main channel of Paraná River (PRb, upstream UPRb and downstream DPRb), at the junction with a secondary channel (TPar), and in a connection channel (ParCh). Within the connection channel (CCh), two sites were sampled: in the center of the channel ( $\mathrm{Chc}$ ) and at the point of joining the lake (ChLak). Four sites were sampled in the permanently connected lake (Lak1, Lak2, Lak3, and Lak4) (Fig. 1). These sites were selected in order to assess the bidirectional pathways between the main river and the lake, and to characterize the different patches included within each habitat.

The macroinvertebrates were sampled four times during the high (November 2009 and March 2010) and low water phases (September 2010 and December 2010) (Fig. 2). Three samples of bottom sediments for benthic invertebrates and one sample for benthic organic matter and granulometric analysis were collected for each sampling date and site using a Tamura grab $\left(319 \mathrm{~cm}^{2}\right)$ in the main channel and an Ekman grab $\left(225 \mathrm{~cm}^{2}\right)$ in the connection channel and in the lake. The Tamura grab is most effective in deep, fast-flowing sandy bottom rivers (Marchese and Ezcurra de Drago, 1992), whereas the Ekman grab is widely used in lakes with silt-clay sediments.

The bottom samples used to collect the benthic invertebrates were filtered through a $200 \mu \mathrm{m}$ sieve and fixed in $10 \%$ formaldehyde in the field. In the laboratory, the organisms were hand-picked from samples under a stereoscopic microscope $(4 \times)$ and preserved in $70 \%$ alcohol for subsequent counting and identification. Identifications were made at the lowest taxonomic level possible (mostly genera or species) using the available keys (Brinkhurst and Marchese, 1992; Lopretto and Tell, 1995; Domínguez and Fernández, 2009; Trivino-Strixino, 2011, among others).

Physical and chemical variables such as depth, transparency (Secchi disk), current velocity (current meter OTT C20 model), temperature (standard thermometer), conductivity (Hanna ${ }^{\circledR}$ conductivity meter), and pH (Hanna ${ }^{\circledR}$ pHmeter) were measured in situ at each sampling site and date. Bottom oxygen concentration (Winkler method; APHA, 1992), benthic particulate organic matter, and granulometric composition of the sediment (Wentworth, 1932) were determined in the laboratory. For the substrate characteristics, the sediment was dried at $100{ }^{\circ} \mathrm{C}$ to a constant mass and benthic particulate organic matter was obtained via ignition (muffle furnace at $550{ }^{\circ} \mathrm{C}$ for $3 \mathrm{~h}$ ).

\section{Data analysis}

Two one-way ANOSIM analyses were run to analyze the similarities in assemblage composition among the spatial (among habitats, regardless of the water level) and temporal (between the high and low water levels, regardless of the habitat) scales, at $\alpha=0.05$ ( $\mathrm{R}$ program, package Vegan; Oksanen et al., 2006).

Redundancy analysis (RDA) was used to assess the relationship between the spatial/temporal variability of the macroinvertebrate data and the environmental variables. This analysis was performed using the R package Vegan (Oksanen et al., 2006). Prior to undertaking the RDA, taxa densities were Hellinger-transformed, as suggested by 


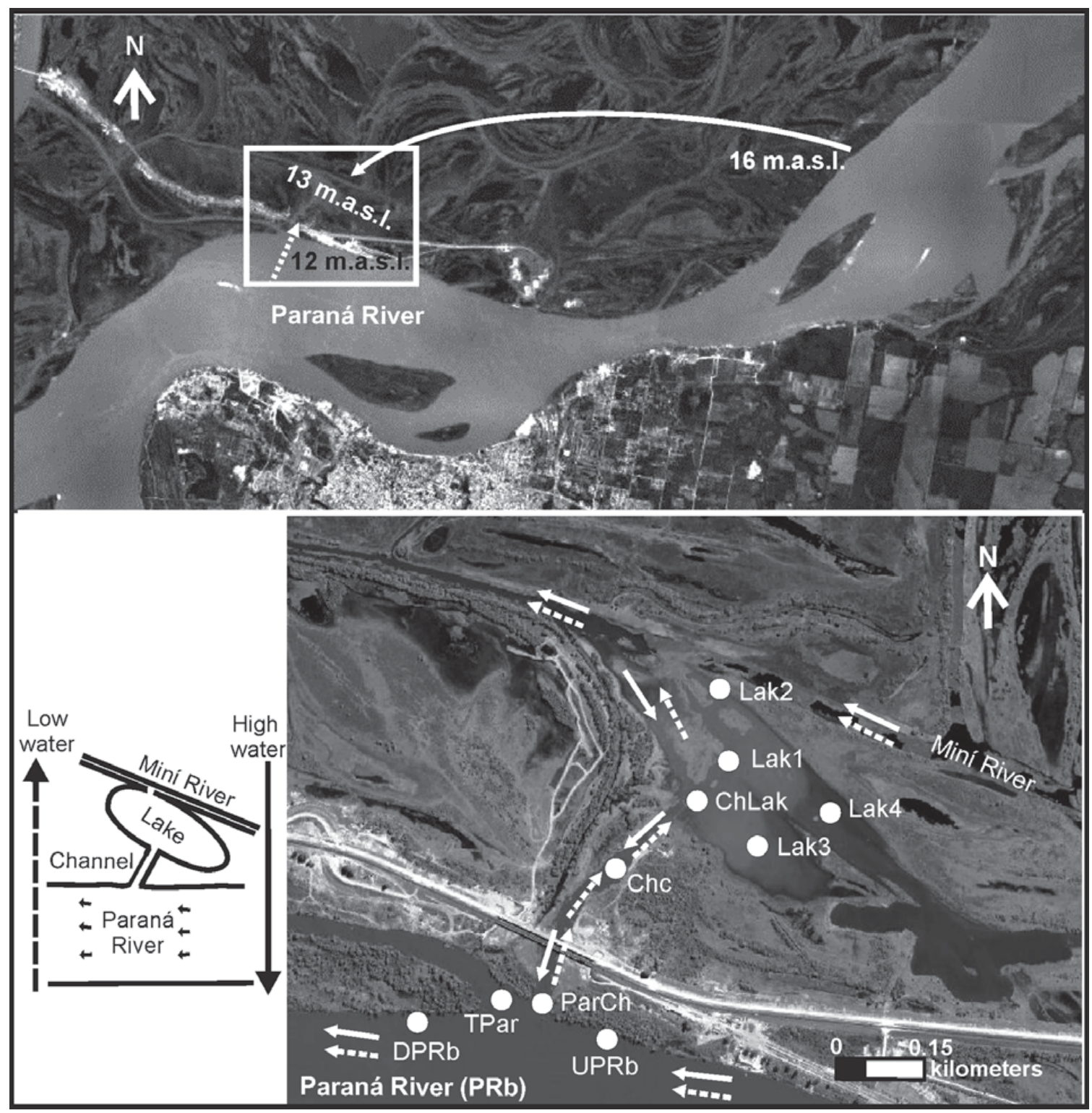

Fig. 1. Map of the Paraná River system, showing the sampling sites within each habitat - Paraná River bank, connection channel and floodplain lake (within the square) - and the main direction of the flow during low (dotted arrows) and high water levels (full arrows). The altitude of the different zones was also included. A scheme indicating the flow direction in the low and high water phase between the river-lateral floodplain habitats was added.

Legendre and Gallagher (2001). The Hellinger transformation preserves Euclidean distance among the rows, and therefore allows the use of Euclidean-based ordination methods. It also offers the advantage of under weighting the rare taxa (Legendre and Gallagher, 2001). The environmental variables were standardized (Legendre and Legendre, 1998), or the arcsine was calculated for the variables expressed as a percentage (Feld and Hering, 2007). This analysis was performed using the $\mathrm{R}$ package Vegan (Oksanen et al., 2006).

The mean density, taxa richness, Shannon diversity, and evenness indexes were compared between water levels and habitats using non-parametric analyses of variance (Kruskal-Wallis test; InfoStat Software estadístico 2010).
The values of taxa richness were first corrected using the rarefaction method (Krebs, 1989) to adjust for unequal sample areas of the grabs. The relationship between the assemblage attributes and the environmental variables was assessed by Spearman correlation ( $R$ package Vegan, Oksanen et al., 2006).

The beta diversity (the spatial turnover of species) was calculated based on presence-absence data in accordance with the modified formula of Whittaker (1973) for pairwise comparisons (Koleff et al., 2003):

$$
\beta_{w}=(a+b+c) /[(2 a+b+c) / 2],
$$

where $a$ is the total number of species shared in both samples, and $b$ and $c$ are the number of species present in 


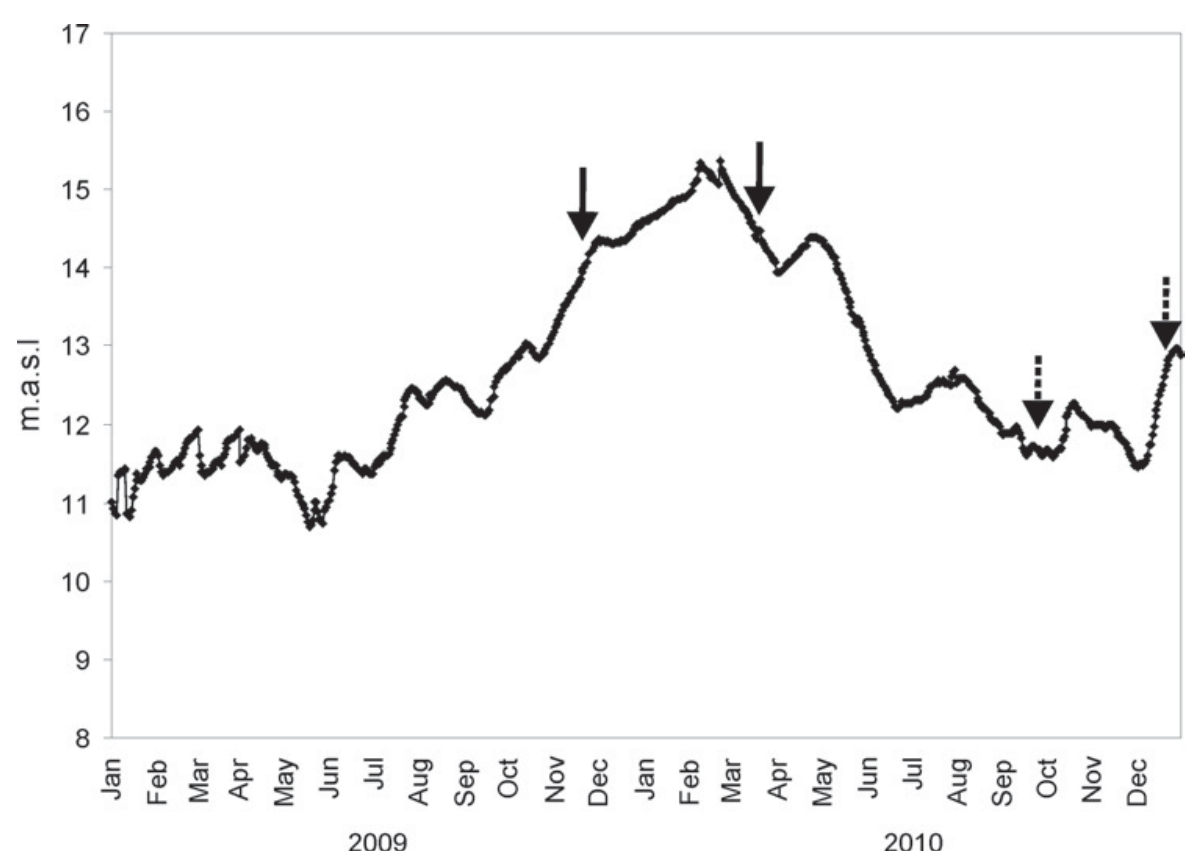

Fig. 2. Water levels (m a.s.1.) of the Middle Paraná River during 2009-2010 (Hydrometric station: Santa Fe Harbor gauge, located at approximately $2.5-3 \mathrm{~km}$ from the studied sites). Arrows indicate the sampling dates. Dotted arrows: low water period; full arrows: high water period.

one sample, but not in the other one, respectively. The maximum $\beta_{\mathrm{w}}$ occurs when the two samples do not share any taxa $(=2)$, whereas the minimum values occur when all the taxa are shared between the samples $(=1)$.

$\beta_{\mathrm{w}}$ was calculated within the sites of each habitat, among the habitats, and among the sites situated in a lateral transect of connectivity from the river to the lake (UPRb, DPRb, ParCh, ChLak, and Lak1). These sites form a corridor across the main channel through the connection channel to the lake (Fig. 1), enabling the detection of the influence of flow direction during high and low water periods. In addition, the resulting values of $\beta_{\mathrm{w}}$ relative to all the sites were related with the geographical distance between pairs of sites (Spearman correlation) in order to detect if the turnover of species was associated with the distance among the sites.

\section{Results}

Values of the limnological variables of the studied habitats in high and low water levels are shown in Figure 3. As water flowed from the floodplain channels to the main river during high water levels and in a inverse direction during low water levels, the mean current velocity was $60 \%$ higher in the Paraná River bank during low water levels than in high water levels, whereas in the connection channel and the lake, the current velocity increased $25-50 \%$ during the high water period (Fig. 3). The current velocity, water depth, and the percentage of sand in the bottom sediment were significantly higher in the Paraná River sites than in the floodplain habitats (Kruskall-Wallis test, $P<0.001$ ), whereas the benthic particulate organic matter and the percentage of silt + clay in the bottom sediment were significantly higher in the floodplain lake (Kruskall-Wallis test, $P<0.001$ ). Within the Paraná River sites, dissolved oxygen was higher during low water levels (Kruskall-Wallis test, $P<0.05$ ). In the floodplain lake, the current velocity, the depth, and water transparency were significantly higher during high water levels (Kruskall-Wallis test, $P<0.01$ ), whereas $\mathrm{pH}$ and dissolved oxygen increased during low water levels (Kruskall-Wallis test, $P<0.01$ ) (Fig. 3).

A total of 93 taxa were identified during the study, with a dominance of Oligochaeta and Diptera (Chironomidae) (35 and 28 taxa, respectively) (Appendix 1). The oligochaetes Aulodrilus pigueti Kowalewski 1914, Limnodrilus hoffmeisteri Kowalewski 1914, Limnodrilus udekemianus Claparede 1862, Pristina acuminate Liag 1958, Pristina americana Cernosvitov 1937, Pristina jenkinae Stephenson 1931, Pristina osborni Walton 1906, the chironomids Axarus sp., Cryptochironomus sp., Polypedilum (Tripodura) sp., Coelotanypus sp., the molluscs Musculium sp., and Nematoda were the shared taxa among the habitats (Appendix 1).

ANOSIM revealed that the composition of assemblages differed significantly among the habitats $(R=0.36$, $P<0.001)$ and between the high and low water levels $(R=0.08, P<0.05)$, although the differentiation among habitats was stronger than that between water levels. This pattern was also shown by RDA, determining the separation of habitats in the ordination space in accordance with different flowing conditions. The first two axes of the RDA accounted for $18 \%$ of the total variance in species data and $30 \%$ of the cumulative percentage variance of the species-environment relationship. The first 

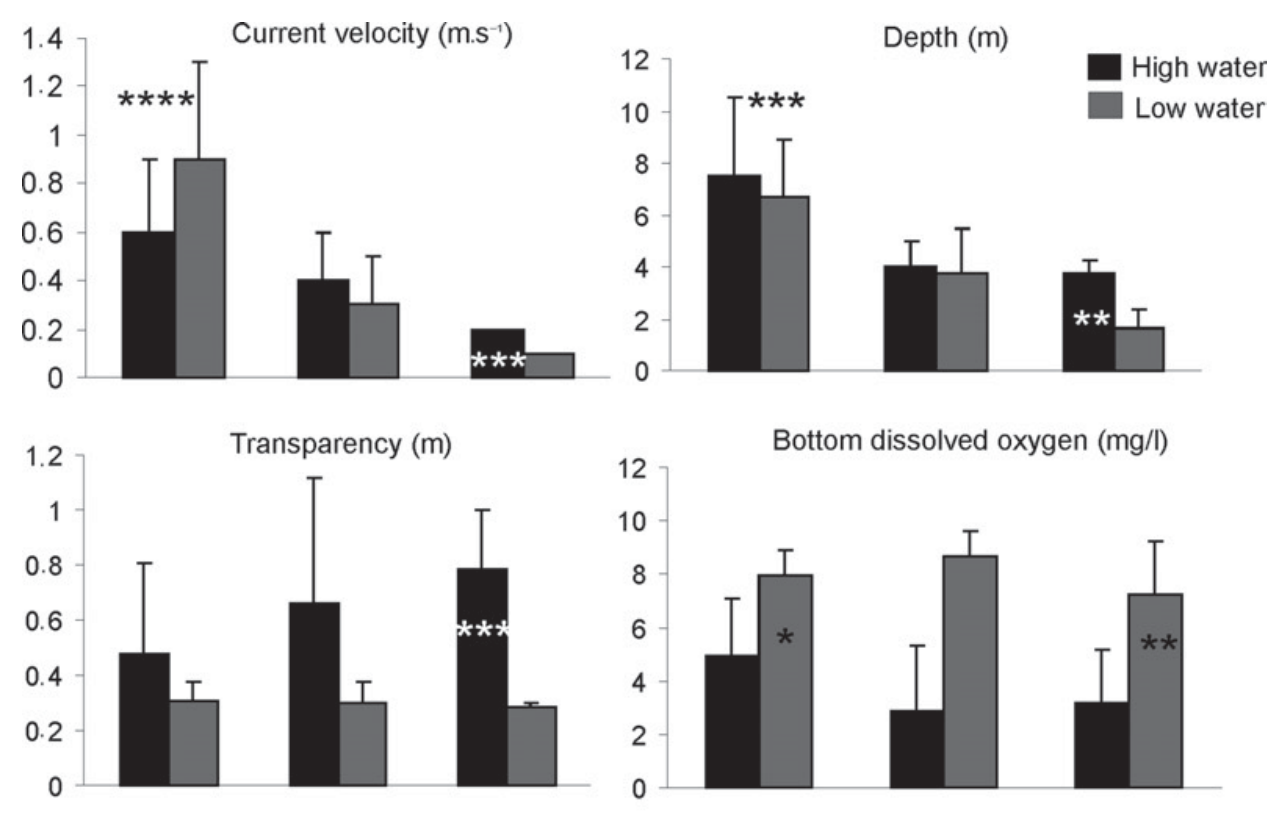

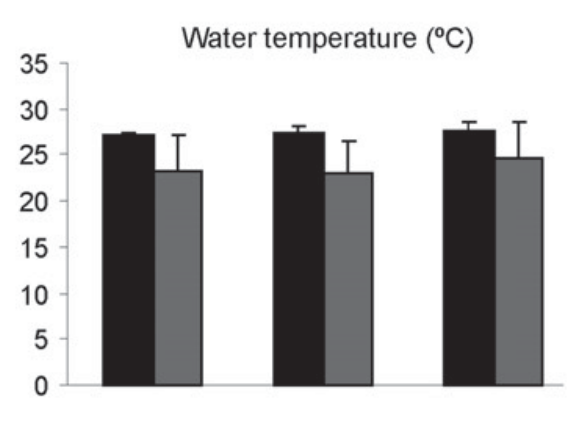

Conductivity $\left(\mu \mathrm{S} . \mathrm{cm}^{-1}\right)$
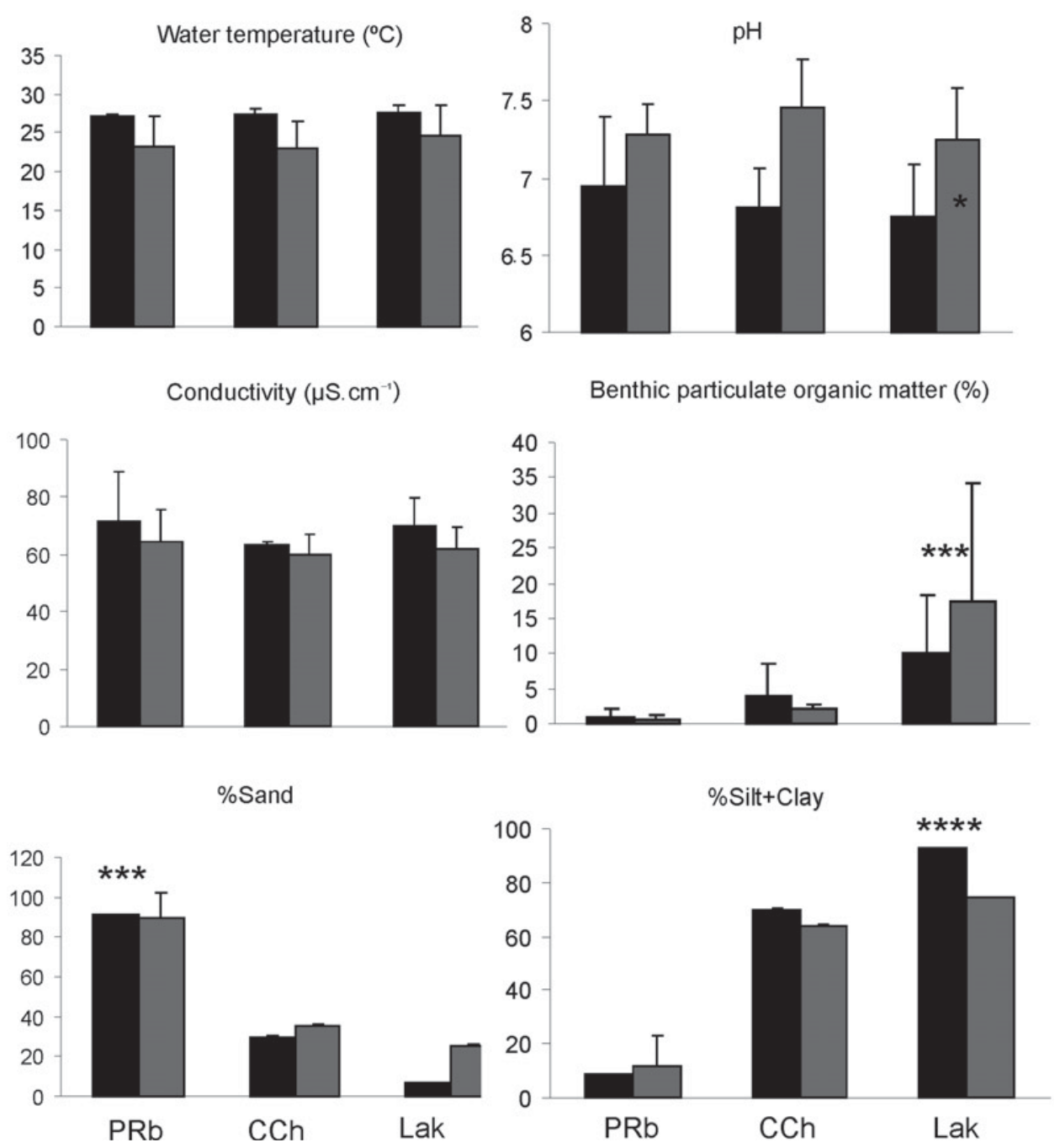

Fig. 3. Mean values $( \pm \mathrm{SD})$ of the environmental variables of each habitat relative to high and low water levels. References: PRb, Paraná River bank; CCh, connection channel; Lak, lake. 

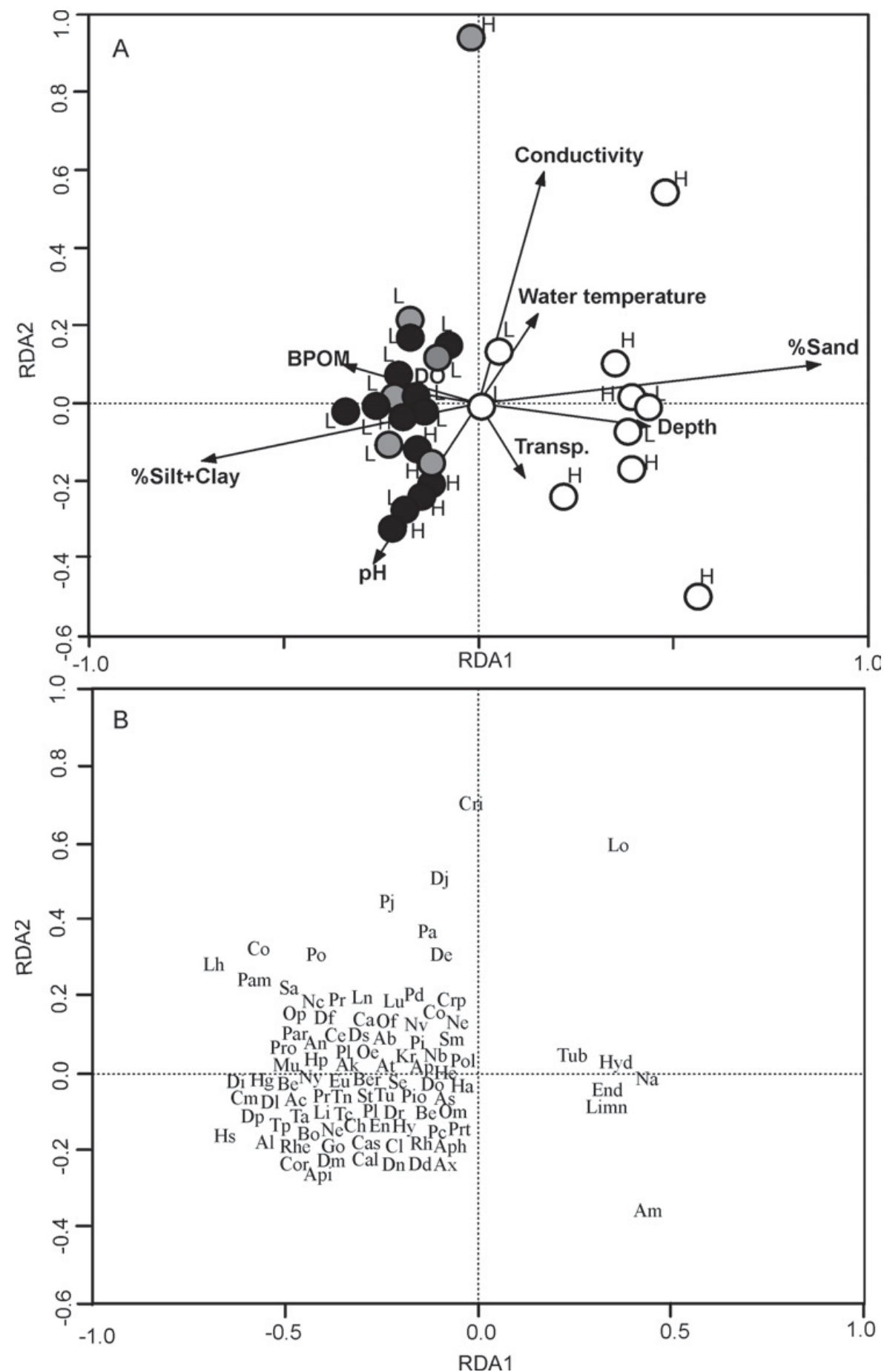

Fig. 4. Redundancy analysis (RDA) of macroinvertebrate density relative to sites of Paraná River (white dots), connection channel (gray dots), and the permanently connected lake (black dots), and their relationship with environmental variables: (A) siteenvironment biplot and (B) taxa ordination. The abbreviation codes of macroinvertebrates are given in Appendix 1. References: DO, dissolved oxygen; Transp., transparency; BPOM, benthic particulate organic matter.

RDA axis (explained variation $=12 \%$ ) separated the habitats with more standing conditions (connection channel and lake) on the left side of the ordination versus the sites of higher water flow (Paraná River bank) in the right side (Fig. 4). Variables such as the percentage of sand $(R=0.80)$ and depth $(R=0.40)$ were highly positively correlated with axis 1 , whereas clay $+\operatorname{silt}(R=-0.60)$ and the benthic particulate organic matter in sediment $(R=-0.31)$ were negatively related with this axis. The second axis (explained variation $=6 \%$ ) represented the gradient of conductivity $(R=0.54)$ and $\mathrm{pH}(R=-0.40)$ among sites (Fig. 4). In the first axis, chironomid 
Table 1. Mean values $( \pm$ SD) of assemblage attributes calculated over all sites relative to each habitat in the two water levels, and results of the non-parametric analysis of variance (Kruskall-Wallis test) used to compare assemblage metrics among the habitats and between high and low water periods. References: PRb = Paraná River bank; CCh = connection channel; Lak $=$ Lake; $\mathrm{n} . \mathrm{s} .=\mathrm{not}$ significant.

\begin{tabular}{lccccc}
\hline Assemblage attributes & $\mathrm{PRb}(n=15)$ & $\mathrm{CCh}(n=6)$ & Lak $(n=13)$ & $\begin{array}{c}P \text { among } \\
\text { habitats }\end{array}$ & $\begin{array}{c}P \text { among } \\
\text { water levels }\end{array}$ \\
\hline Taxa richness & $1.8(2.5)$ & $11.3(5.8)$ & $22.1(7.6)$ & $<0.0001$ & n.s. \\
Density (ind.m ${ }^{-2}$ ) & $32(1.9)$ & $4034(165)$ & $4442(99)$ & $<0.0001$ & n.s. \\
Shannon-Wiener index & $0.14(0.25)$ & $0.57(0.38)$ & $0.89(0.15)$ & $<0.0001$ & n.s. \\
Evenness & $0.23(0.4)$ & $0.55(0.37)$ & $0.69(0.13)$ & n.s. & n.s. \\
\hline
\end{tabular}

Endotribelos sp., oligochaetes Narapa bonettoi Righi and Varela 1983, Limnodrilus sp. and Tubicidae inmature, trichopteran Hydroptilidae and ephemeropteran Americabaetis sp. were associated with the Paraná River sites, whereas a total of 86 taxa were related with the floodplain habitats. In the second axis, Criptochironomus sp., Djalmabatista sp. and Pristina jenkinae were associated with the connection channel and at high water levels (Fig. 4).

The taxa richness, the density, and Shannon diversity differed among habitats within the river-lake system (Kruskall-Wallis test, $P<0.0001$ ), but did not show significant differences between the water levels (KruskallWallis test, $P>0.05$ ) (Table 1). The richness, density, and diversity were higher in the lake and connection channel than at sites of the Paraná River bank (Table 1, Fig. 5). The lowest density was found in the Paraná River bank, where the chironomid Axarus sp. dominated in density (mean density $=18$ ind. $\mathrm{m}^{-2}$ ). In addition, Axarus sp. and Musculium sp. were dominant in the connection channel (2409 and 1830 ind. $\mathrm{m}^{-2}$, respectively), whereas Nematoda and $A$. pigueti were dominant in the lake habitat (1490 and 797 ind. $\mathrm{m}^{-2}$, respectively). The taxa richness, density, and diversity were positively correlated with benthic particulate organic matter and percentage of silt + clay and negatively related with the depth and the percentage of sand in the bottom sediments (Table 2). Evenness was positively related with benthic particulate organic matter and the percentage of silt + clay and negatively related with current velocity. In addition, the current velocity was negatively related with taxa richness and diversity (Table 2).

The values of beta diversity were significantly lower within each habitat than among them (within habitats $=$ mean $\beta_{\mathrm{w}} 1.58$, among habitats $=$ mean $\beta_{\mathrm{w}} 1.75$; Kruskall-Wallis test, $P=0.01$ ). In addition, the turnover of species was positively related with the geographical distance (Spearman correlation, $R=0.56, P<0.001$ ). In the selected sites situated in the main channel-connection channel-lake corridor (UPRb, DPRb, ParCh, ChLak, and Lak1), $\beta_{\mathrm{w}}$ differed between the water levels (KruskallWallis test, $P=0.01$ ), being significantly higher during the high water period. Thus, during this phase, when the direction of the flow was from the lake to the river, $\beta_{\mathrm{w}}$ showed the maximum value of turnover $(=2)$ at most of the sites. On the other hand, when the direction of the flow was inverse (during low water levels), the values of $\beta_{\mathrm{w}}$ were
Increase in density, species diversity and richness

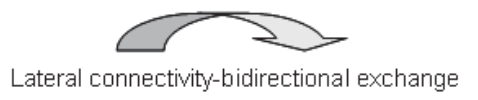

Main channel of Paraná River

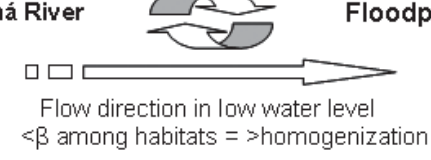

ک

Flow direction in high water level

$>\beta$ among habitats $=>$ heterogeneity

Fig. 5. Flow direction in low and high water levels in the lateral connectivity main channel of Paraná River - floodplain habitats, and its effect on beta diversity.

lower, indicating a lower turnover of species (Table 3). This condition determined that the turnover of species was mostly related with the direction of water flow within the river-connected lake system (Fig. 5).

\section{Discussion}

In the present study, the topography and position of the floodplain lake within the river corridor determined that the flow was mainly directed from the floodplain to the main channel during the high water phase and in the opposite direction during the low water period. It is important to point out that the main direction of the flow during the low water phase in the studied system was inverted to that usually observed in field measurements (Paoli and Schreider, 2000). This observation was related to the scale of the analysis, the regional slope, and the position of the studied sites in the floodplain. In addition, the strongest homogenization of benthic assemblage composition occurred during low water levels, which was inferred by the lower values of species turnover between the sites located in the main channel-lake corridor during this water level. In contrast, during the high water phase, lower current velocity from the lake to the river would produce a lower displacement of invertebrates (i.e., drift), increasing the species turnover among sites. Thus, we obtained an atypical pattern with a higher dissimilarity among the habitats during floods than during the drought period, in comparison with the results reported by Thomaz et al. (2007), which found a homogenization among the floodplain habitats during floods in the 
Table 2. Results of correlation analysis between environmental variables recorded at all sites on high and low water periods and assemblage attributes relative to all sites and water levels.

\begin{tabular}{|c|c|c|c|c|}
\hline & Taxa richness & Density (ind. $\mathrm{m}^{-2}$ ) & Shannon-Wiener index & Evenness \\
\hline Current velocity $\left(\mathrm{m} \cdot \mathrm{s}^{-1}\right)$ & $-0.64 * *$ & -0.34 & $-0.61 * *$ & $-0.50 * *$ \\
\hline Depth (m) & $-0.61 * *$ & $-0.61 * *$ & $-0.55^{* *}$ & -0.2 \\
\hline Transparency (m) & 0.09 & 0.03 & 0.24 & 0.2 \\
\hline Bottom dissolved oxygen (mg. $\left.\mathrm{L}^{-1}\right)$ & -0.16 & -0.17 & -0.01 & 0.06 \\
\hline Water temperature $\left({ }^{\circ} \mathrm{C}\right)$ & 0.26 & 0.24 & 0.14 & -0.07 \\
\hline $\mathrm{pH}$ & -0.22 & -0.29 & -0.13 & -0.16 \\
\hline Conductivity $\left(\mu \mathrm{S} . \mathrm{cm}^{-1}\right)$ & -0.07 & -0.1 & 0.04 & -0.07 \\
\hline Benthic particulate organic matter $(\%)$ & $0.74 * * *$ & $0.75^{* * *}$ & $0.68 * *$ & $0.39 *$ \\
\hline Sand $(\%)$ & $-0.77 * * *$ & $-0.78 * * *$ & $-0.70 * * *$ & -0.33 \\
\hline Silt + clay $(\%)$ & $0.75^{* * *}$ & $0.48^{*}$ & $0.74 * * *$ & $0.50 * *$ \\
\hline
\end{tabular}

$* P<0.05 ; * * P<0.01 ; * * * P<0.001$.

Table 3. Values of beta diversity among sites located in the corridor main channel-connection channel-lake during high and low water levels. In bold: values for high water level; underlined: values relative to low water level. The direction of the rows indicates the main direction of the flow among sites in different hydrological periods. Site references: UPRb, DPRb: bank of the main channel of the Paraná River upstream and downstream, respectively; ParCh, point of connection of Paraná River with the channel; ChLak, the point of connection of the channel with the lake; Lak1, within the permanently connected lake.

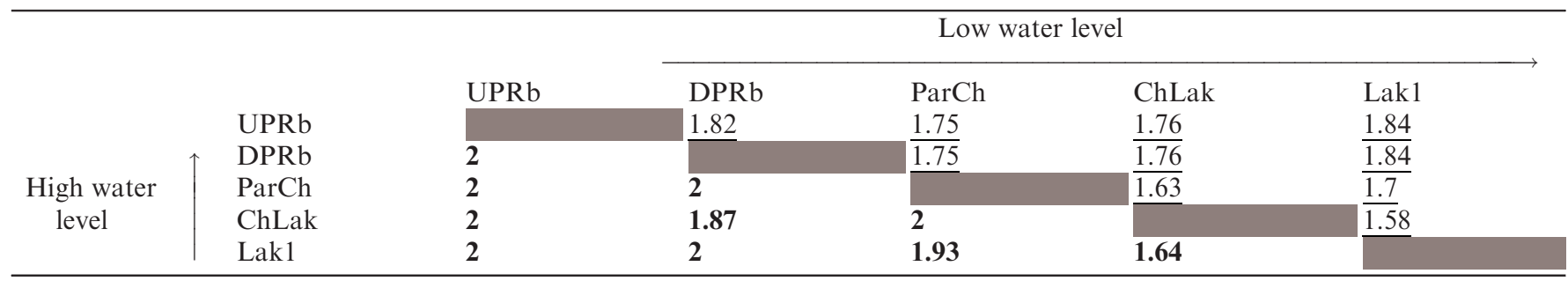

neotropical and temperate systems. In general, the results of our work were related to the studied spatial scale and ordinary hydrological period, while at a greater increase of water level (e.g., extraordinary hydrological period, such as the ENSO), flooding tends to generate uniformity among the habitats by creating maximum connectivity, while the receding water levels re-establish heterogeneity, with maximum singularities of biotic assemblages (Ward and Tockner, 2001; Ezcurra de Drago et al., 2007; Thomaz et al., 2007; Zilli and Montalto, 2011).

Beta diversity increased with geographical distance, indicating that the homogenization in species composition was less effective at greater distances, so that species assemblages from more distant sites reflected different environmental conditions prevailing there. Furthermore, the species favored by certain habitats would have a higher probability of migrating to adjacent habitats of similar quality (Forbes and Chase, 2002; Mormul et al., 2011).

In our study, several environmental characteristics of the habitats, such as sediment granulometry, organic matter in the sediment, and depth, were more important than differences in water level in explaining the patterns of assemblage structure. This finding is not surprising, as it is well established that small-scale physical characteristics influence macroinvertebrate composition (Takeda and Fujita, 2004; Hieber et al., 2005; Ezcurra de Drago et al., 2007). The low effect of water level on benthic attributes could be explained by the low variations in water level and by the permanent connection of the lake with the main river, as was reported by previous studies of the Middle Paraná River floodplain (Ezcurra de Drago et al., 2007). In this sense, a higher water level or extraordinary events, such as Southern Oscillation (ENSO), that produce an increase in magnitude, duration, and intensity of the flood, would produce a significant structural change in macroinvertebrate assemblages in the studied system, as was reported by Marchese et al. (2002) and Ezcurra de Drago et al. (2007).

In addition, we found an increase in the diversity, abundance, and richness from the main river to the lake, and this result was in accordance with other studies of large rivers, showing an increase in complexity from the main channel to the floodplain waterbodies (Tockner et al., 1998; Garcia and Laville, 2001; Amoros and Bornette, 2002; Arscott et al., 2005; Ezcurra de Drago et al., 2007; Reese and Batzer, 2007; Gallardo et al., 2008; Behrend et al., 2009). Lower species diversity, richness, and density near the bank of the main channel may be explained by low organic matter content and granulometry of the sediments, and by high current velocity that excludes lentic organisms as these are not adapted to maintain their position to prevent accidental loss under high current velocity (Bogatov et al., 1995; Dudgeon, 1995; Takeda et al., 2001; Ezcurra de Drago et al., 2004, 2007). The chironomid Axarus sp. was dominant in riverine assemblages of Paraná River, and this finding was in accordance with other studies in large rivers, such as the Paraguay River (Takeda et al., 2000; Ezcurra de Drago et al., 2004; Marchese et al., 2005). 
In addition, the assemblage composition (Nematoda, A. pigueti, L. hoffmeisteri, P. acuminata, Coelotanypus sp., Polypedilum (Tripodura) sp., Hirudinea, Musculium sp., Corbicula sp., and Heleobia spp.) recorded in the studied lentic systems, was reported as representative of other floodplain habitats directly connected to the river with abundant benthic organic matter and silt-clayed sediment (Marchese et al., 2002; Marchese and Ezcurra de Drago, 2006; Zilli et al., 2008; Zilli and Marchese, 2011).

The natural water outflow from the main river is extremely important for the exchange of propagules, nutrients, and organisms among the habitats. Such exchanges are mandatory to retain high biodiversity that is unique to river floodplain systems (Neiff, 2001; Amoros and Bornette, 2002). This is because this flow increases the probability of rare species dispersing and colonizing new sites during floods, promoted by high hydrological connectivity (Thomaz et al., 2007). Furthermore, we found that water flow direction caused significant differences in beta diversity between high and low water periods in a river-connected system, showing that the complexity of the patterns of diversity within this gradient was regulated by lateral bidirectional exchanges among the habitats. These exchanges are essential to maintain particular invertebrate diversity of large river corridors. Therefore, the regulation of river flow represents a real problem for these systems due to interference in lateral connectivity, and consequent loss of biodiversity (Tockner et al., 2011). Thus, the conservation of high levels of macroinvertebrate diversity in large river systems may depend on preserving natural variation in hydrological connectivity and flow regimes of unregulated rivers.

Acknowledgements. The authors are grateful for financial support from the Consejo Nacional de Investigaciones Científicas y Técnicas (CONICET) and the Universidad Nacional del Litoral (UNL). We also thank Dr. Hugo Fernández and Paola Rueda Martín for their assistance in sample identification. We greatly appreciate the constructive comments and suggestions on the manuscript made by Dr Martin Pusch of the IGB, the two anonymous reviewers, and by the Editor in-chief. The English of the manuscript was reviewed by Language Editor.

\section{References}

Amoros C. and Bornette G., 2002. Connectivity and biocomplexity in waterbodies of riverine floodplains. Freshwater Biol., 47, 761-776.

Amoros C., Roux A.L., Reygrobellet J.L., Bravard J.P. and Pautou G., 1987. A method for applied ecological studies of fluvial hydrosystems. Regul. Rivers, 1, 17-36.

APHA 1992. Standard Methods for the Examination of Water and Wastewater (18th edn,), American Public Health Association, Washington, DC, USA.

Arscott D.B., Tockner K. and Ward J.V., 2005. Lateral organization of aquatic invertebrates along the corridor of a braided floodplain river. J. N. Am. Benthol. Soc., 24, 934-954.
Behrend R.D.L., Fernandes S.E.P., Fujita D.S.A. and Takeda A.M., 2009. Eight years of monitoring aquatic Oligochaeta from the Baía and Ivinhema Rivers. Braz. J. Biol., 69, 559-571.

Bogatov V., Sirotsky S. and Yuriev D., 1995. The ecosystem of the Amur river. In: Cushing C.E., Cummins K.W. and Minshall, G.W. (eds.), River and Stream Ecosystems, Elsevier, New York, USA, 601-613.

Brinkhurst R.O. and Marchese M. 1992. Guía para la identificación de Oligoquetos acuáticos continentales de Sud y Centroamérica. Asociación de Ciencias Naturales del Litoral Colección Climax No. 6, Segunda Edición, Asociación de Ciencias Naturales del Litoral, Santa Fe, Argentina, 207 p.

Bunn S.E. and Arthington A.H., 2002. Basic principles and ecological consequences of altered flow regimes for aquatic biodiversity. Environ. Manage., 30, 492-507.

Domínguez E. and Fernández H.R. 2009. Macroinvertebrados bentónicos Sudamericanos, Fundación Miguel Lillo, Tucumán, Argentina, 654 p.

Drago E.C., 1990. Hydrological and geomorphological characteristics of flood-plain ponds in the middle Paraná River. Acta Limnol. Bras., 3, 907-930.

Drago E.C., 2007. The physical dynamics of the river-lake floodplain system. In: Iriondo H., Paggi J.C. and Parma M.J. (eds.), The Middle Paraná River Limnology of a Subtropical Wetland, Springer-Verlag, Berlin, Heidelberg, New York, USA, 82-122.

Dudgeon D., 1995. The ecology of rivers and streams in tropical Asia. In: Cushing C.E., Cummins K.W. and Minshall G.W. (eds.), River and Stream Ecosystems, Elsevier, New York, USA, 615-657.

Ezcurra de Drago I., Marchese M. and Wantzen K.M., 2004. Benthos of a large neotropical river: spatial patterns and species assemblages in the Lower Paraguay and its floodplains. Arch. Hydrobiol., 160, 347-374.

Ezcurra de Drago I., Marchese M. and Montalto L., 2007. Benthic invertebrates. In: Iriondo H., Paggi J.C. and Parma M.J. (eds.), The Middle Paraná River Limnology of a Subtropical Wetland, Springer-Verlag, Berlin, Heidelberg, New York, 251-275.

Feld C.K. and Hering D., 2007. Community structure or function: effects of environmental stress on benthic macroinvertebrates at different spatial scales. Freshwater Biol. 52, 1380-1399.

Forbes A.E. and Chase J.M., 2002. The role of habitat connectivity and landscape geometry in experimental zooplankton metacommunities. Oikos, 96, 433-440.

Gallardo B., García M., Cabezas A., González E., González M., Ciancarelli C. and Comín F.A., 2008. Macroinvertebrate patterns along environmental gradients and hydrological connectivity within a regulated river-floodplain. Aquat. Sci., 70, 248-258.

Garcia X.F. and Laville H., 2001. Importance of floodplain waters for the conservation of chironomid (Diptera) biodiversity in a 6th order section of the Garonne river (France). Ann. Limnol., 37, 35-47.

Hieber M., Robinson C.T., Uehlinger U. and Ward J.V., 2005. A comparison of macroinvertebrate assemblages among different types of alpine streams. Freshwater Biol., 50, 2087-2100.

InfoStat. Software estadístico. 2010. Facultad de Ciencias Agropecuarias, Universidad Nacional de Córdoba, Argentina.

Junk W.J., 1999. The flood pulse concept of large rivers: learning from tropics. Arch. Hydrobiol. Suppl., 115, 261-280. 
Junk W.J., Bayley P.B. and Sparks R.E., 1989. The flood pulse concept in river-floodplain systems. Special Publ. Can. J. Fish. Aquat. Sci., 106, 110-127.

Koleff P., Gaston K.J. and Lennon J.J., 2003. Measuring beta diversity for presence-absence data. J. Anim. Ecol., 72, 367-382.

Krebs C.J. 1989. Ecological Methodology, Harper Collins Publishers, New York.

Legendre P. and Gallagher E.D., 2001. Ecologically meaningful transformations for ordination of species data. Oecologia, 129, 271-280.

Legendre P. and Legendre L. 1998. Numerical Ecology (Second English edition,), Elsevier Science BV, Amsterdam, The Netherlands.

Lopretto E.C. and Tell G., 1995. Ecosistemas de aguas continentales. Ediciones Sur, La Plata, Argentina, 1401 p.

Marchese M. and Ezcurra de Drago I.E., 1992. Benthos of the lotic environments in the middle Paraná River system: transverse zonation. Hydrobiologia, 237, 1-13.

Marchese, M. and Ezcurra de Drago I., 2006. Bentos como indicador de condiciones tróficas del sistema del río Paraná Medio. In: Tundisi J., Matsumura Tundisi T. and Sidagis Galli C. (eds.), Eutrofização na América do Sul: Causas, Consequências e Tecnologias de Gerenciamento e Controle, San Paulo, Brazil, 297-316.

Marchese M., Ezcurra de Drago I. and Drago E., 2002. Benthic macroinvertebrates and physical habitat relationships in the Paraná River flood-plain system. In: McClain M.E. (ed.), The Ecohydrology of South American Rivers and Wetlands, Special Publication No. 6, IAHS, 111-130.

Marchese M., Wantzen K.M. and Ezcurra de Drago I., 2005. Benthic invertebrate assemblages and species diversity patterns of the Upper Paraguay. Riv. Res. Appl., 21, 131-144.

Mormul R.P., Thomaz S.M., Takeda A.M. and Behrend R.D., 2011. Structural complexity and distance from source habitat determine invertebrate abundance and diversity. Biotropica, 1-8.

Neiff J.J., 2001. Diversity in some tropical wetland systems of South America. In: Gopal B., Junk W.J. and Davis J.A. (eds.), Biodiversity in Wetlands: Assessment, Function and Conservation, Backhuys Publishers, Leiden, 157-186.

Oksanen J., Kindt R., Legendre P. and O'Hara R.B., 2006. Vegan: Community Ecology Package version 1.17-4, http://cran.r-project.org/web/packages/vegan/index.html

Paoli C. and Schreider M. 2000. El río Paraná en su tramo medio. Tomo I, Universidad Nacional del Litoral, Santa Fe, Argentina, $307 \mathrm{p}$.

Poff N.L., 1997. Landscape filters and species traits: towards mechanistic understanding and prediction in stream ecology. J. N. Am. Benthol. Soc., 16, 391-409.

Ramonell C.G., Amsler M.L. and Toniolo H., 2000. Geomorfología del cauce principal. In: Paoli C. and Schreider M. (eds.), El río Paraná en su tramo medio, Tomo I, Centro de Publicaciones, Secretaría de Extensión UNL, Santa Fe, Argentina, 175-232.

Reese E.G. and Batzer D.P., 2007. Do invertebrate communities in floodplains change predictably along a rivers length? Freshwater Biol., 52, 226-239.

Takeda A.M. and Fujita D.S., 2004. Benthic invertebrates. In: Thomaz S.M., Agostinho A.A. and Hanh N.S. (eds.), The Upper Parana River and its Floodplain: Physical Aspect,
Ecology and Conservation, Backhuys Publishers, Leiden, The Netherlands, 191-208.

Takeda A.M., Callisto M. and Barbosa F., 2000. Zoobenthos survey of the Pantanal, Mato Grosso do Sul, Brasil. In: Willink P.W., Chernoff B., Alonso L.E., Montambault J.R. and Lourival R. (eds.), A Biological Assessment of the Aquatic Ecosystems of the Pantanal, Mato Grosso do Sul, Brasil. RAP Bulletin of Biological Assessment 18. Conservation International, 168-174.

Takeda A.M., Stevaux J.C. and Fujita D.S., 2001. Effect of hydraulics, bed load grain size and water factor on habitat and abundance of Narapa bonettoi Righi and Varela, 1983 of the Upper Paraná River, Brazil. Hydrobiologia, 463, 241-248.

Thomaz S.M., Bini L.M. and Bozelli R.L., 2007. Floods increase similarity among aquatic habitats in river-floodplain systems. Hydrobiologia, 1, 1-13.

Thorp J.H., Thoms M.C. and DeLong M.D., 2006. The riverine ecosystem synthesis: biocomplexity in river networks across space and time. Riv. Res. Appl., 22, 123-147.

Tockner K., Schiemer F. and Ward J.V., 1998. Conservation by restoration: the management concept for a riverfloodplain system on the Danube River in Austria. Aquat. Conserv., 8, 71-86.

Tockner K., Malard F. and Ward J.V., 2000. An extension of the flood pulse concept. Hydrol. Process., 14, 2861-2863.

Tockner K., Pusch M., Gessner J., and Wolter C., 2011. Domesticated ecosystems and novel communities: challenges for the management of large rivers. Ecohydrol. Hydrobiol., 11, 167-174.

Trivinho Strixino S. 2011. Larvas de Chironomidae. Guía de identificação, Dpto. De Hidrobiologia, Lab. De Entomologia Aquática, UFSCar, São Carlos, Brazil. 371 p.

Wantzen K.M. and Junk W.J., 2000. The importance of streamwetland-systems for biodiversity: a tropicalperspective. In: Gopal B., Junk W.J. and Davis J.A. (eds.), Biodiversity in Wetlands: Assessment, Function and Conservation, Backhuys Publishers, Leiden, 11-34.

Ward J.V. and Stanford J.A., 1995. Ecological connectivity in alluvial river ecosystems and its disruption by flow regulation. Reg. Riv., 11, 105-19.

Ward J.V. and Tockner K., 2001. Biodiversity: towards a unifying theme for river ecology. Freshwater Biol., 46, 807-19.

Ward J.V., Tockner K. and Schiemer F., 1999. Biodiversity of floodplain river ecosystem. Ecotones and connectivity. Reg. Riv. Res. Manag., 15, 125-139.

Wentworth C., 1932. A scale of grade and class terms for clastic sediments. J. Geol., 30, 377-392.

Whittaker R.H., 1973. Evolution and measurement of species diversity. Taxon, 21, 213-251.

Zilli F.L. and Marchese M.R., 2011. Patterns in macroinvertebrate assemblages at different spatial scales. Implications of hydrological connectivity in a large floodplain river. Hydrobiologia, 663, 245-257.

Zilli F.L. and Montalto L., 2011. Benthic invertebrates in the middle Paraná River floodplain (Argentina). In: Álvarez M. (ed.), Floodplains: Physical Geography, Ecology and Societal Interactions, Nova Science Publishers Inc., Hauppauge, NY, 99-126.

Zilli F.L., Montalto L. and Marchese M.R., 2008. Benthic invertebrate assemblages and functional feeding groups in the Paraná River floodplain (Argentina). Limnologica, 38, 159-171. 
Appendix 1. Mean density (ind. $\mathrm{m}^{-2}$ ) of macroinvertebrate taxa relative to the three studied habitats and abbreviations used in the Redundancy analysis. PRb $=$ Paraná River bank; $\mathrm{CCh}=$ connection channel; Lak = Lake.

\begin{tabular}{|c|c|c|c|c|c|}
\hline & Taxa & Abbreviations & $\mathrm{PRb}$ & $\mathrm{CCh}$ & Lak \\
\hline Turbellaria & & & 0 & 1.4 & 2.3 \\
\hline \multirow[t]{36}{*}{ Nematoda } & & $\mathrm{Ne}$ & 4.1 & 27.2 & 1470.1 \\
\hline & Aulodrilus limnobius & $\mathrm{Al}$ & 0 & 7.4 & 37.6 \\
\hline & Aulodrilus pigueti & Api & 2.1 & 170.4 & 797.7 \\
\hline & Bothrioneurum sp. & Bo & 0 & 0 & 3.4 \\
\hline & Limnodrilus sp. & Limn & 1.4 & 0 & 78.6 \\
\hline & Limnodrilus hoffmeisteri & $\mathrm{Lh}$ & 1.0 & 219.8 & 312.3 \\
\hline & Limnodrilus neotropicus & $\mathrm{Ln}$ & 0 & 6.2 & 8.0 \\
\hline & Limnodrilus udekemianus & $\mathrm{Lu}$ & 1.0 & 9.9 & 3.4 \\
\hline & Paranadrilus descolei & $\mathrm{Pd}$ & 0 & 2.5 & 1.1 \\
\hline & Enchytraeidae & En & 0 & 0.0 & 1.1 \\
\hline & Dero sp. & De & 0 & 2.5 & 3.4 \\
\hline & Dero lodeni & Dl & 0 & 4.9 & 4.6 \\
\hline & Dero digitata & $\mathrm{Dd}$ & 0 & 0 & 4.6 \\
\hline & Dero furcatus & Df & 0 & 0 & 1.1 \\
\hline & Dero multibranchiata & $\mathrm{Dm}$ & 0 & 0 & 8.0 \\
\hline & Dero nivea & Dn & 0 & 0 & 3.4 \\
\hline & Dero obtusa & Do & 0 & 0 & 12.5 \\
\hline & Dero plumosa & $\mathrm{Dp}$ & 0 & 0 & 2.3 \\
\hline & Dero righii & Dr & 0 & 0 & 6.8 \\
\hline & Dero sawayai & Ds & 0 & 0 & 6.8 \\
\hline & Pristina acuminata & $\mathrm{Pa}$ & 2.1 & 65.4 & 129.9 \\
\hline & Pristina americana & Pam & 5.5 & 23.4 & 6.8 \\
\hline & Pristina jenkinae & $\mathrm{Pj}$ & 0.6 & 2.5 & 13.7 \\
\hline & Pristina leidyi & $\mathrm{Pl}$ & 0 & 0 & 3.4 \\
\hline & Pristina osborni & Pro & 0.6 & 8.5 & 27.4 \\
\hline & Stephensoniana trivandrana & St & 0 & 0 & 30.8 \\
\hline & Nais communis & $\mathrm{Nc}$ & 0 & 0 & 4.5 \\
\hline & Nais variabilis & $\mathrm{Nv}$ & 0 & 12.3 & 4.5 \\
\hline & Nais bretscheri & $\mathrm{Nb}$ & 0 & 2.5 & 0.0 \\
\hline & Slavina evelinae & $\mathrm{Se}$ & 0 & 1.4 & 2.3 \\
\hline & Narapa bonettoi & $\mathrm{Na}$ & 1.4 & 0 & 0 \\
\hline & Opistocystidae n.i. & $\mathrm{Op}$ & 0 & 0 & 8.0 \\
\hline & Trieminentia corderoi & Tc & 0 & 0 & 13.7 \\
\hline & Opistocysta funiculus & Of & 0 & 0 & 2.3 \\
\hline & Opistocysta $\mathrm{sp}$ & $\mathrm{Op}$ & 0 & 0 & 6.8 \\
\hline & Tubicidae & Tub & 1.0 & 4.9 & 4.6 \\
\hline Hirudinea & & $\mathrm{Hi}$ & 0 & 19.8 & 175.5 \\
\hline \multirow[t]{22}{*}{ Chironomidae } & Ablabesmyia spp. & $\mathrm{Ab}$ & 0 & 0 & 1.1 \\
\hline & Ablabesmyia (karelia) & Ak & 0 & 0 & 4.6 \\
\hline & Ablabesmyia (annulatta) & An & 0 & 0 & 6.8 \\
\hline & Asheum sp. & As & 0 & 0 & 2.3 \\
\hline & Axarus sp. & $\mathrm{Ax}$ & 18.8 & 2409.9 & 23.9 \\
\hline & Beardius sp. & $\mathrm{Be}$ & 0 & 0 & 1.1 \\
\hline & Caladomya sp. & Cal & 0 & 0 & 4.6 \\
\hline & Caladomya ortoni & Co & 0 & 0 & 1.1 \\
\hline & Chironomus sp. & $\mathrm{Ch}$ & 0 & 0 & 13.7 \\
\hline & Cladopelma sp. & $\mathrm{Cl}$ & 0 & 0 & 2.3 \\
\hline & Coelotanypus sp. & $\mathrm{Co}$ & 0.6 & 14.2 & 51.9 \\
\hline & Cricotopus sp. & Cri & 2.0 & 28.0 & 6.0 \\
\hline & Cryptochironomus spp. & Crp & 2.1 & 28.4 & 5.7 \\
\hline & Dicrotendipes sp. & $\mathrm{Di}$ & 0 & 0 & 2.3 \\
\hline & Djalmabatista sp. & $\mathrm{Dj}$ & 0 & 12.3 & 4.6 \\
\hline & Endotribelos sp. & End & 0.7 & 0 & 0 \\
\hline & Goeldichironomus sp. & Go & 0 & 0 & 2.3 \\
\hline & Harnischia sp. & $\mathrm{Ha}$ & 0 & 0 & 5.7 \\
\hline & Nymbocera rhabdomantis & $\mathrm{Ny}$ & 0 & 0 & 1.1 \\
\hline & Lopescladius sp. & Lo & 0.4 & 3.9 & 0 \\
\hline & Parachironomus sp. & $\mathrm{Pc}$ & 0 & 2.5 & 0 \\
\hline & Paralauterborniella sp. & Par & 0 & 0 & 17.1 \\
\hline
\end{tabular}




\begin{tabular}{|c|c|c|c|c|c|}
\hline & Taxa & Abbreviations & $\mathrm{PRb}$ & $\mathrm{CCh}$ & Lak \\
\hline & Paratanytarsus $\mathrm{sp}$. & Prt & 0 & 0 & 1.1 \\
\hline & Polypedilum (Tripodura) sp. & Po & 16.0 & 170.9 & 133.0 \\
\hline & Procladius sp. & $\operatorname{Pr}$ & 0 & 0 & 13.7 \\
\hline & Rheocricotopus sp. & $\mathrm{Rh}$ & 0 & 0 & 1.1 \\
\hline & Rheotanytarsus sp. & Rhe & 0 & 0 & 8.0 \\
\hline & Saetheria sp. & $\mathrm{Sa}$ & 0 & 5.1 & 28.0 \\
\hline & Tanytarsus alfredoi & Taa & 0 & 0 & 11.4 \\
\hline & Tanypus punctipennis & $\mathrm{Tp}$ & 0 & 0 & 10.3 \\
\hline & Tanytarsus alfredoi & $\mathrm{Ta}$ & 0 & 0 & 11.4 \\
\hline & Tanytarsini sp. & $\mathrm{Tn}$ & 0 & 0 & 21.7 \\
\hline Ceratopogonidae & & $\mathrm{Ce}$ & 0 & 0 & 20.0 \\
\hline \multirow[t]{2}{*}{ Ephemeroptera } & Americabaetis sp. & $\mathrm{Am}$ & 0.5 & 0 & 0 \\
\hline & Caenis sp. & $\mathrm{Ca}$ & 0 & 2.5 & 3.4 \\
\hline \multirow[t]{6}{*}{ Trichoptera } & Campsurus sp. & $\mathrm{Cm}$ & 0 & 0 & 42.2 \\
\hline & Hydroptilidae & Hyd & 0.6 & 0 & 0 \\
\hline & Neotrichia sp. & $\mathrm{Ne}$ & 0 & 10.0 & 0 \\
\hline & Oecetis sp. & Oe & 0 & 0 & 2.3 \\
\hline & Polycentropodidae & Pol & 1.1 & 0 & 0 \\
\hline & Smicridea $\mathrm{sp}$ & $\mathrm{Sm}$ & 0 & 7.4 & 0 \\
\hline Hemiptera & & $\mathrm{He}$ & 0 & 0 & 1.1 \\
\hline Coleoptera & Berosus sp. & Ber & 0 & 0 & 2.3 \\
\hline Odonata & Aphylla sp. & Aph & 0 & 2.5 & 1.1 \\
\hline \multirow{5}{*}{ Acarina } & Aturidae & At & 0 & 1.4 & 3.4 \\
\hline & Piona sp. & Pio & 0 & 0 & 1.1 \\
\hline & Hygrobatella sp. & Hy & 0 & 0 & 1.1 \\
\hline & Krendowchidae & $\mathrm{Kr}$ & 0 & 0 & 1.1 \\
\hline & Limnesiidae & $\mathrm{Li}$ & 0 & 4.9 & 3.4 \\
\hline \multirow[t]{11}{*}{ Mollusca } & Ancyilidae & Ac & 0 & 0 & 11.4 \\
\hline & Asolene pulchella & Ap & 0 & 2.5 & 1.1 \\
\hline & Heleobia guaranitica & $\mathrm{Hg}$ & 0 & 24.2 & 166.4 \\
\hline & Heleobia parchappei & $\mathrm{Hp}$ & 0 & 0 & 39.9 \\
\hline & Omalonix sp. & $\mathrm{Om}$ & 0 & 0 & 1.1 \\
\hline & Castalia sp. & Cas & 0 & 0 & 1.1 \\
\hline & Eupera sp. & $\mathrm{Eu}$ & 0 & 0 & 5.7 \\
\hline & Musculium sp. & $\mathrm{Mu}$ & 1.7 & 1830.5 & 372.3 \\
\hline & Pisidium sp. & $\mathrm{Pi}$ & 0 & 0 & 1.1 \\
\hline & Corbicula & Cor & 0 & 10.0 & 77.5 \\
\hline & Planorbidae & $\mathrm{P} 1$ & 0 & 0 & 5.7 \\
\hline
\end{tabular}

